\title{
LYVE1 wt Allele
}

National Cancer Institute

\section{Source}

National Cancer Institute. LYVE1 wt Allele. NCI Thesaurus. Code C97288.

Human LYVE1 wild-type allele is located in the vicinity of $11 \mathrm{p} 15$ and is approximately $11 \mathrm{~kb}$ in length. This allele, which encodes lymphatic vessel endothelial hyaluronic acid receptor 1 protein, plays a role in binding hyaluronan and may regulate intracellular transport of hyaluronan. 